Original Research Article

\title{
Oral clonidine: an effective adjuvant in functional endoscopic sinus surgery
}

\author{
Amit Kumar Ray ${ }^{1}$, Anjana Basu Ghosh Dastidar ${ }^{1 *}$, Bani P. M. Hembrom²
}

${ }^{1}$ Department of Anaesthesiology and Critical Care Medicine, R.G. Kar Medical College. Kolkata, West Bengal, India ${ }^{2}$ Department of

Anaesthesiology, Midnapore Medical College, Midnapore, West Bengal, India

Received: 27 August 2017 Accepted: 21 September 2017

*Correspondence to:

Dr. Anjana Basu Ghosh

Dastidar,

Email: anjanag_dastidar@ yahoo.co.in

Copyright: (C) the author(s), publisher and licensee Medip Academy. This is an openaccess article distributed under the terms of the Creative Commons Attribution NonCommercial License, which permits unrestricted noncommercial use, distribution, and reproduction in any medium, provided the original work is properly cited.

\begin{abstract}
Background: A comparative study to evaluate the efficacy of intravenous Dexmedetomidine as a hypotensive agent in comparison to oral Clonidine in Endoscopic Nasal Surgery or Functional Endoscopic Sinus Surgery (FESS).

Methods: Forty patients ASA I or II scheduled for Endoscopic Nasal Surgery were equally randomly assigned to receive either dexmedetomidine $1 \mu \mathrm{g} / \mathrm{Kg}$ over $10 \mathrm{~min}$ before induction of anesthesia followed by $0.5 \mu \mathrm{g} / \mathrm{Kg} / \mathrm{h}$ infusion during maintenance (Group D), or oral Clonidine (Group C) $2 \mu \mathrm{g} / \mathrm{kg}$ with minimal water 1 hour prior starting of surgery. Rescue bolus doses of Propofol (10mg/dose) were given to maintain mean arterial blood pressure (MAP) between $(50-70 \mathrm{mmHg}$ ). General anesthesia was maintained with Isoflurane 1\%-2\%. The surgical field was assessed using Average Category Scale. Hemodynamic variables (MAP and $\mathrm{HR}$ ) were recorded at 10 minutes interval.

Results: Both group C and group D reached the desired MAP $(50-70 \mathrm{mmHg})$ with no intergroup differences in HR but a statistically significant lower MAP was noticed in group $\mathrm{C}$. The quality of the surgical field in the range of MAP (50$70 \mathrm{mmHg}$ ) were 2-3 as per average category Scale with significantly lower score in Group C. Mean intraoperative propofol consumption was significantly higher in group $\mathrm{D}$ than $\mathrm{C}$ group.

Conclusions: Both Dexmedetomidine or oral clonidine with isoflurane are safe agents for controlled hypotension, but oral clonidine provides lower MAP and better surgical field. Compared with Dexmedetomidine, oral clonidine offers the advantage of less consumption of propofol.
\end{abstract}

Keywords: Controlled hypotension, Dexmedetomidine, Nasal endoscopic surgery, Oral clonidine

\section{INTRODUCTION}

Functional endoscopic sinus surgery (FESS) is a minimally invasive technique that is used to treat chronic sinusitis. Small bleeding areas can significantly compromise operative visibility and result in destruction of surrounding structures. ${ }^{1,2}$ Deliberate hypotension (lowering the mean arterial blood pressure to between 50 and $70 \mathrm{mmHg}$ in normotensive patients) using a range of pharmacological agents during general anaesthesia reduces blood loss in many operations. Clonidine and
Dexmedetomidine both centrally acting $\alpha 2$ agonist constricts peripheral blood vessels, heart rate, cardiac output and reduces systemic blood pressure, which in combination decrease nasal mucosa blood flow. ${ }^{1,3}$ These effects can potentially reduce bleeding during Nasal Endoscopic Surgery and stabilize the intraoperative hemodynamic profile of the patient. In this present study we propose to compare the effectiveness of oral Clonidine and intravenous Dexmedetomidine in stabilization of haemodynamic profile of patients and intraoperative visibility for patients undergoing Nasal Endoscopic 
surgery under general anaesthesia and also to detect untoward effects if any.

\section{METHODS}

After approval of the Institutional Ethical Committee, this single centred prospective randamized double blinded study was conducted at our institution from July 2013 to January 2014. Written informed consent was obtained after proper counselling from each patient.

Inclusion Criteria were Adult patients (18 - 65 years of age) of either sex and ASA physical status 1 and 2 . Exclusion Criteria were Heart rate $<70 /$ minute, basal Systolic B.P. $<100 \mathrm{~mm}$ of $\mathrm{Hg}$ or $>160 \mathrm{~mm}$ of $\mathrm{Hg}$. History of known cardiovascular, pulmonary, renal, hepatic or Neurological disease, history of allergy to study drugs, pregnancy, lactation and history of using beta blockers. 40 patients thus selected were randomly divided into two groups - Group C (Clonidine group, $n=20$ ), Group D (Dexmedetomidine group, $\mathrm{n}=20$ ).

Complete preanaesthetic evaluation was performed in each patient including detailed history taking, thorough physical examination and routine preoperative investigations. History of co-existing diseases and allergy to study drugs was recorded, as also baseline study variables (B.P, Heart rate).

Patients were sedated with Tab. Alprazolam $0.25 \mathrm{mg}$ at the bed time on the day before operation and kept on standard ASA fasting guidelines.

Group C patients were given Tab. Clonidine $(2 \mu \mathrm{gm} / \mathrm{kg})$ with minimal amount of water 1 hour prior anticipated anasethetic induction time. On arrival on the operating room patients baseline parameters i.e. heart rate (HR), Systolic blood pressure (SBP), diastolic blood pressure (DBP), mean arterial pressure (MAP), ECG, oxygen saturation was noted. An intravenous line was started with Ringers Lactate solution.

Group D patients received Inj. Dexmedetomidine $(1 \mu \mathrm{gm} / \mathrm{kg})$ as loading dose over 15 minutes and $0.5 \mu \mathrm{gm} / \mathrm{kg} / \mathrm{hr}$ as maintenance dose thereafter till the end of surgery.

All patients were preoxygenated with $100 \%$ oxygen for 3 minutes and Inj. Fentanyl $2 \mu \mathrm{gm} / \mathrm{kg}$ i.v., inj. Glycopyrrolate $4 \mu \mathrm{gm} / \mathrm{kg}$ i.v., inj. Ondansetron $4 \mathrm{mg} / \mathrm{kg}$ i.v. and inj. Midazolam 2mg i.v. was given to them. All the patients were induced with i.v Propofol (1\%) upto loss of verbal command (maximum upto $3 \mathrm{mg} / \mathrm{kg}$ ) and this was followed by i.v Succinylcholine $1.5 \mathrm{mg} / \mathrm{kg}$ as muscle relaxant to facilitate laryngoscopy and intubation. Endotracheal intubation was done under direct laryngoscopic vision. Anaesthesia was maintained with Nitrous oxide $(66 \%)+$ Oxygen $(33 \%)+$ Inj. Vecuronium i.v. in conventional doses and Isoflurane at $1 \%-2 \%$. Analgesia was maintained with Inf. Paracetamol i.v.
Anaesthesia was maintained by conventional protocols and was reversed with Inj. Neostigmine and Inj. Glycopyrrolate in conventional doses. The heart rate, NIBP was recorded just prior to induction (base line value), 1 minute after completion of intubation and every 10 minutes interval thereafter. Any intraoperative hypertensive episodes were managed with rescue bolus doses of Propofol (10mg/bolus). Incidences of untoward effects if any were noted.

The surgical field was graded in terms of bleeding by the operating surgeon using Six-point Average Category Scale (from no bleeding: 0, Slight bleeding no suctioning of blood required: 1, Slight bleeding - suctioning not required, surgical field not threatened: 2 , slight bleeding frequent suctioning required, bleeding threatens surgical field few seconds after removal of suction: 3 , moderate bleeding - frequent suctioning required, bleeding threatens surgical field directly after suction is removed: 4 , severe bleeding - constant suctioning required. Bleeding appears faster than can be removed by suction. Surgical field severely threatened and surgery is not possible: 5). ${ }^{4}$ The ideal category scale values for surgical conditions were predetermined to be two and three.

Patient details and study data was recorded in individual case record forms and was considered for analysis. All raw data was entered into MS Excel ${ }^{\mathrm{TM}}$ spreadsheet and analyzed using standard statistical software.

Categorical variables (e.g. propofol requirement) was analyzed using the Pearson's chi square test. Numerical variables between groups which are normally distributed were analyzed using the student's t test.

\section{RESULTS}

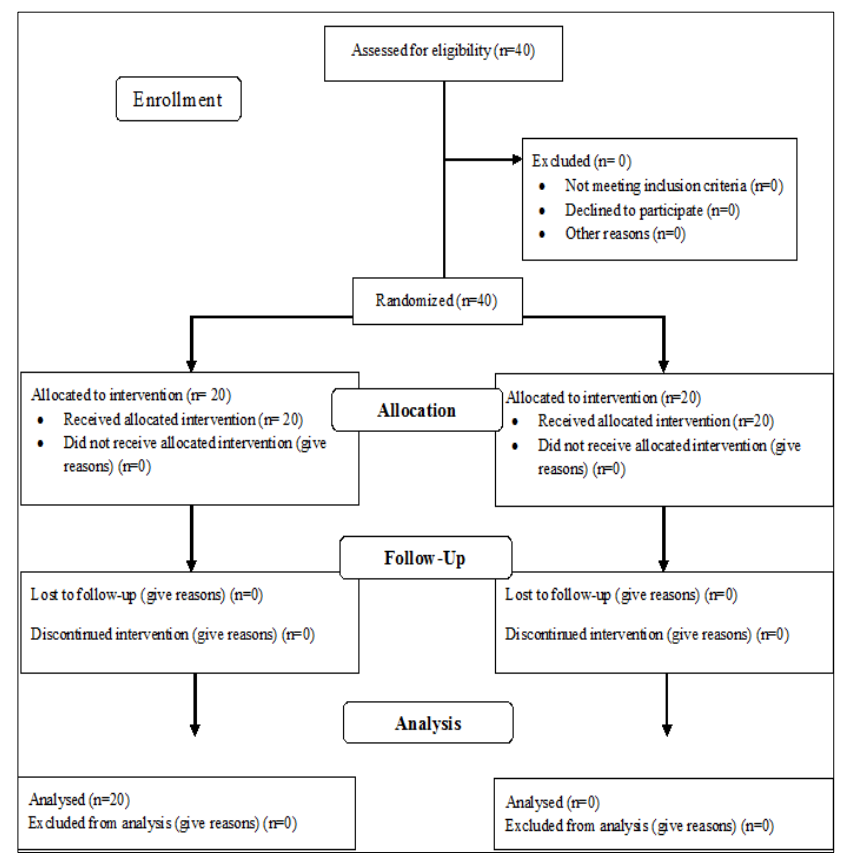

Figure 1: Consort 2010 flow diagram. 
A total of 40 patients were included in this study, Group C and Group D having 20 patients in each group. Patients of the study groups were comparable with respect to demographic data.

The duration of surgery was $78.1 \pm 14.3 \mathrm{~min}$ and $80 \pm 13.6$ min for group $\mathrm{C}$ and $\mathrm{D}$ respectively. Base line values of MAP and HR were comparable in both groups. In C and D groups, there was a significant reduction of intraoperative MAP and heart rate in both groups compared to that of baseline value. The MAP between Group C and Group D just after intubation were comparable. But there was significantly lower ( $\mathrm{p}<0.05$ ) MAP in Group $\mathrm{C}$ than that of Group D when the MAP was measured at 10 min interval intraoperatively thereafter.

Table 1: Patients characteristics.

\begin{tabular}{|lll|}
\hline & Gr C & Gr D \\
\hline Age (years) & $40(10)$ & $41(13)$ \\
\hline Male & 9 & 12 \\
\hline Female & 11 & 8 \\
\hline Weight $(\mathrm{kg})$ & $52(8)$ & $51(10)$ \\
\hline
\end{tabular}

Table 2: Comparison between MAP ( $\mathrm{mm}$ of $\mathbf{H g})$.

\begin{tabular}{|c|c|c|c|c|c|c|c|c|c|c|}
\hline & Base line & Intubation & $10 \mathrm{~min}$ & $20 \mathrm{~min}$ & $30 \mathrm{~min}$ & $40 \mathrm{~min}$ & $50 \mathrm{~min}$ & $60 \mathrm{~min}$ & $70 \mathrm{~min}$ & $80 \mathrm{~min}$ \\
\hline $\mathrm{GrC}$ & $\begin{array}{l}88.6 \\
(5.68)\end{array}$ & $\begin{array}{l}94.8 \\
(8.12)\end{array}$ & $\begin{array}{l}69.95 \\
(6.41)\end{array}$ & $\begin{array}{l}65.45 \\
(5.43)\end{array}$ & $\begin{array}{l}63.8 \\
(5.43)\end{array}$ & $\begin{array}{l}62.8 \\
(6.35)\end{array}$ & $\begin{array}{l}65.25 \\
(5.23)\end{array}$ & $\begin{array}{l}68.15 \\
(3.48)\end{array}$ & $\begin{array}{l}67.25 \\
(5.85)\end{array}$ & $\begin{array}{l}67 \\
(4.36)\end{array}$ \\
\hline Gr D & $\begin{array}{l}86.7 \\
(6.77)\end{array}$ & $\begin{array}{l}92.9 \\
(7.76)\end{array}$ & $\begin{array}{l}76 \\
(6.7)\end{array}$ & $\begin{array}{l}72.85 \\
(6.24)\end{array}$ & $\begin{array}{l}69.9 \\
(6.16)\end{array}$ & $\begin{array}{l}70.25 \\
(8)\end{array}$ & $\begin{array}{l}71.3 \\
(6.14)\end{array}$ & $\begin{array}{l}72 \\
(4.79)\end{array}$ & $\begin{array}{l}70 \\
(4.58)\end{array}$ & $\begin{array}{l}70.2 \\
(4.27)\end{array}$ \\
\hline
\end{tabular}

There was no significant difference $(\mathrm{p}>0.05)$ in HR among these two groups intraoperatively.

Table 3: Comparison between heart rate (per minute).

\begin{tabular}{|c|c|c|c|c|c|c|c|c|c|c|}
\hline & Base line & Intubation & $10 \mathrm{~min}$ & $20 \mathrm{~min}$ & 30 min & $40 \mathrm{~min}$ & $50 \mathrm{~min}$ & $60 \mathrm{~min}$ & $70 \mathrm{~min}$ & $80 \mathrm{~min}$ \\
\hline Gr C & $\begin{array}{l}82.05 \\
(13.14)\end{array}$ & $\begin{array}{l}88.8 \\
(12.28)\end{array}$ & $\begin{array}{l}74.1 \\
(10.28)\end{array}$ & $\begin{array}{l}67.7 \\
(9.64)\end{array}$ & $\begin{array}{l}65.15 \\
(8.68)\end{array}$ & $\begin{array}{l}63.5 \\
(8.15)\end{array}$ & $\begin{array}{l}65 \\
(8.18)\end{array}$ & $\begin{array}{l}65.6 \\
(6.06)\end{array}$ & $\begin{array}{l}63.5 \\
(5.8)\end{array}$ & $\begin{array}{l}65.4 \\
(5.52)\end{array}$ \\
\hline Gr D & $\begin{array}{l}78.25 \\
(13.67)\end{array}$ & $\begin{array}{l}85.7 \\
(12.59)\end{array}$ & $\begin{array}{l}69.1 \\
(9.99)\end{array}$ & $\begin{array}{l}65.95 \\
(9.51)\end{array}$ & $\begin{array}{l}63.2 \\
(7.74)\end{array}$ & $\begin{array}{l}62.6 \\
(8.11) \\
\end{array}$ & $\begin{array}{l}62.8 \\
(6.58)\end{array}$ & $\begin{array}{l}64.95 \\
(6.98)\end{array}$ & $\begin{array}{l}68 \\
(4.9)\end{array}$ & $\begin{array}{l}67.3 \\
(4.67)\end{array}$ \\
\hline
\end{tabular}

The bolus Propofol requirement to achieve the target MAP were significantly higher $(\mathrm{p}<0.05)$ in Group D. 7 out of 20 patients in Group C required Propofol whereas 15 out of 20 patients in Group D required Propofol to achieve target MAP.

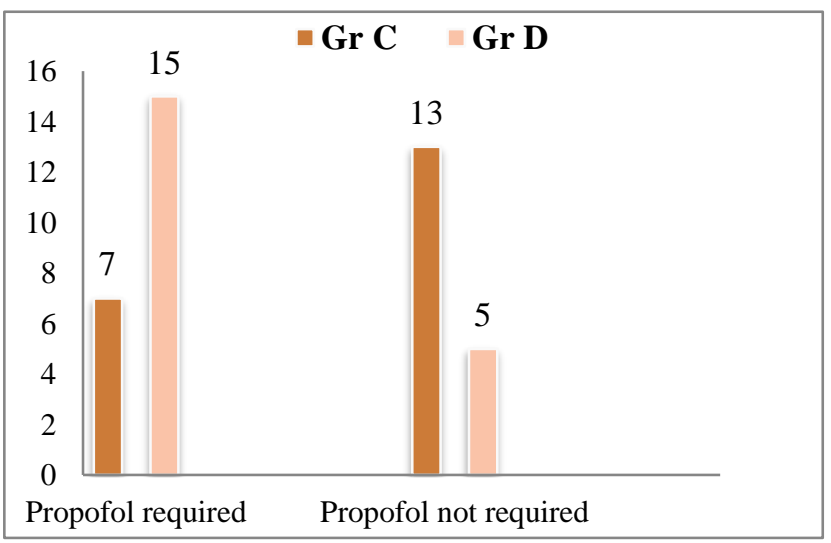

Figure 2: Requirement of propofol.

Patients receiving Clonidine presented significantly lower surgical field bleeding scores than those receiving Dexmedetomidine [mean (SD) Average Category Scale 2.3 (0.53) vs. 2.9 (0.79), p <0.05].

\section{DISCUSSION}

A lot of efforts have been done to optimize the surgical conditions for FESS. Induced hypotension has been widely advocated to control bleeding during FESS to improve the quality of surgical field. ${ }^{5,6}$ This Dexmedetomidine induced hemodynamic profile can be attributed to the known sympatholytic effect of $\alpha 2$ agonists. The $\alpha 2$-receptors are involved in regulating the autonomic and cardiovascular systems. $\alpha 2$-receptors are located on blood vessels, where they mediate vasoconstriction, and on sympathetic terminal, where they inhibit, norepinephrine release. ${ }^{7}$ At lower doses, the dominant action of $\alpha 2$ agonist is sympatholysis. ${ }^{8}$

Sies'kiewicz et al, evaluated the relationship between mean arterial pressure and perioperative bleeding during FESS in patients with a low heart rate. ${ }^{9}$ They found that intraoperative bleeding is largely a function of MAP and $\mathrm{HR}$ : when the HR is maintained at $60 \mathrm{beats} / \mathrm{min}$, there is no need, in many cases, to intensively reduce bleeding to achieve optimal surgical conditions. In that same study Sies 'kiewicz and colleagues used the Fromm and Boezzart scale to evaluate perioperative bleeding and surgical field visibility. They found good results with an MAP between 65 and $78 \mathrm{~mm} \mathrm{Hg} .{ }^{9,10}$ However, generalized use of such a 
low blood pressure might be risky depending on the age of the patient; consequently, an individualized approach should be used. Theoretically, the decreased heart rate extends the diastolic duration and increases filling in the vessels, which ultimately results in increased cardiac output and bleeding in the operative field..$^{11,12}$

Clonidine has gained popularity over the last 40 years mainly as an antihypertensive drug. ${ }^{13}$ It seems that besides central alpha 2 adrenergic receptors agonistic effect, it also affects peripheral alpha1 adrenergic receptors causing vasoconstriction. Administration of clonidine does not affect the baroreceptor reflexes but reduces its sensibility. ${ }^{14}$

In our study we found that Clonidine causes better reduction in intraoperative blood pressure than Dexmedetomidine. There is no significant difference in intraoperative heart rate between these two drugs. But the intraoperative Propofol consumption to achieve and maintain target MAP was significantly more in Dexmedetomidine group than that of Clonidine group. The surgical field scoring (Average Category Scale) was lower in Clonidine group compared to Dexmedetomidine group and hence the bleeding was also less in Clonidine group. In our country like India, particularly in government setup hospitals where the majority of patients come from lower socioeconomic status use of oral Clonidine in fiberoptic nasal surgery may be a cost effective choice as both the Dexmedetomidine and Propofol are costlier than that of oral Clonidine.

\section{CONCLUSION}

This study demonstrates that both clonidine and dexmedetomidine are safe in fiberoptic nasal surgery. But Clonidine causes better blood pressure reduction, less Propofol consumption and better surgical field compared to Dexmedetomidine. Therefore, oral clonidine may be considered as a cost effective choice comparing to Dexmedetomidine in fiberoptic nasal surgeries.

Funding: No funding sources

Conflict of interest: None declared

Ethical approval: The study was approved by the Institutional Ethics Committee

\section{REFERENCES}

1. Mohseni M, Ebneshahidi A. The effect of oral clonidine premedication on blood loss and the quality of the surgical field during endoscopic sinus surgery: a placebo-controlled clinical trial. J Anesth. 2011;25:614-7.
2. Ahn HJ, Chung SK, Dhong HJ, Kim HY. Comparison of surgical conditions during propofol or sevoflurane anesthesia for endoscopic sinus surgery. $\mathrm{Br} \mathrm{J}$ Anaesthesia. 2008;100:50-4.

3. Schmelling WT, Kampine JP, Roerig DL, Warltier DC. The effect of the stereoisomers of the $\alpha 2$-adrenergic agonist dexmedetomidine on systemic and coronary haemodynamics in conscious dogs. Anesthesiology. 1991;75:499-511.

4. Fromme GA, MacKenzie RA, Gould AB Jr, Lund BA, Offord KP. Controlled hypotension for orthognatic surgery. Anesth Analg. 1986;65:683-6.

5. Eberhart LH, Folz BJ, Wulf H, Geldner G. Intravenous anesthesia provides optimal surgical conditions during microscopic and endoscopic sinus surgery. Laryngoscope. 2003;113:1369-73.

6. Cincikas D, Ivaskevicius S. Application of controlled arterial hypotension in endoscopic rhino -surgery. Medicina (Kaunas). 2003;39:852-9.

7. Langer SZ. Presynaptic regulation of the release of catecholamines. Pharmacol Rev. 1980;32:337-62.

8. McCallum JB, Boban N, Hogan Q, Schmeling WT, Kampine JP, Bosnjak ZJ. The mechanism of alpha-2 adrenergic inhibition of sympathetic ganglionic transmission Anesth Analg. 1998;87:503-10.

9. Sies'kiewicz A, Drozdowski A, Rogowski M. The assessment of correlation between mean arterial pressure and intraoperative bleeding during endoscopic sinus surgery in patients with low heart rate. Otolaryngol Pol. 2010;64(4):225-8.

10. Boezzart AP, van der Merve J, Coetzee A. Comparison of sodium nitroprusside and esmolol induced controlled hypotension for functional endoscopic sinus surgery. Can J Anaesth. 1995;42:373-6.

11. Nair S, Collins M, Hung P, Rees G, Close D, Wormald PJ. The Effect of $\beta$-Blocker Premedication on the Surgical Field During Endoscopic Sinus Surgery. The Laryngoscope. 2004 Jun 1;114(6):1042-6.

12. Simpson P. Perioperative blood loss and its reduction: the role of the anaesthetist. BJA: British Journal of Anaesthesia. 1992 Nov 1;69(5):498-507.

13. Hall DL, Rezvan E, Tatakis DN, Walters JD. Oral clonidine pretreatment prior to venous cannulation. Anesthesia progress. 2006 Jun;53(2):34-42.

14. Kamibayashi T, Maze M. Perioperative use of alfa-2 adrenergic agonists. Curr Opin Anaesth. 1996;9:3237 .

Cite this article as: Ray AK, Dastidar ABG, Hembrom BPM. Oral clonidine: an effective adjuvant in functional endoscopic sinus surgery. Int $\mathbf{J}$ Basic Clin Pharmacol 2017;6:2631-4. 